\title{
Hyperspectral analysis for perioperative perfusion monitoring-a clinical feasibility study on free and pedicled flaps
}

\author{
D. G. E. Thiem ${ }^{1}$ (D) R. W. Frick ${ }^{1}$ - E. Goetze ${ }^{1}$ - M. Gielisch ${ }^{1}$ • B. Al-Nawas ${ }^{1,2} \cdot$ P. W. Kämmerer ${ }^{1}$
}

Received: 16 March 2020 / Accepted: 26 May 2020 / Published online: 15 June 2020

(C) The Author(s) 2020

\begin{abstract}
Objectives In reconstructive surgery, flap monitoring is crucial for early identification of perfusion problems. Using hyperspectral imaging (HSI), this clinical study aimed to develop a non-invasive, objective approach for perfusion monitoring of free and pedicled flaps.

Material and methods HSI of 22 free (FF) and 8 pedicled flaps (PF) in 30 patients was recorded over time. Parameters assessed were tissue oxygenation/superficial perfusion $(0-1 \mathrm{~mm})\left(\mathrm{StO}_{2}(0-100 \%)\right)$, near-infrared perfusion/deep perfusion $(0-4 \mathrm{~mm})$ (NIR (0-100)), distribution of haemoglobin (THI $(0-100))$, and water (TWI $(0-100))$. Measurements up to $72 \mathrm{~h}$ were correlated to clinical assessment.

Results Directly after flap inset, mean $\mathrm{StO}_{2}$ was significantly higher in FF $(70.3 \pm 13.6 \%)$ compared with PF $56.2 \pm 14.2 \%(p=$ 0.05 ), whereas NIR, THI, and TWI were similar (NIR $p=0.82$, THI $\_=0.97$, TWI $\_=0.27$ ). After $24 \mathrm{~h}, \mathrm{StO}_{2}$, NIR, THI, and TWI did not differ between FF and PF. After $48 \mathrm{~h}, \mathrm{StO}_{2}$, NIR, and TWI did not differ between FF and PF whereas THI was significantly increased in FF compared with $\operatorname{PF}(p=0.001)$. In three FF, perfusion decreased clinically and in HSI, $36^{(1)}, 40^{(2)}$, $5^{(3)}$, and $61^{(3)} \mathrm{h}$ after flap inset which was followed by prompt intervention.

Conclusions $\mathrm{StO}_{2}<40 \%, \mathrm{NIR}<25 / 100$, and $\mathrm{THI}<40 / 100$ indicated arterial occlusion, whereas venous problems revealed an increase of THI. In comparison with FF, perfusion parameters of PF were decreased after flap transfer but remained similar to FF later on.

Clinical relevance HSI provides objective and non-invasive perfusion monitoring after flap transplantation in accordance to the clinical situation. With HSI, signs of deterioration can be detected hours before clinical diagnosis.
\end{abstract}

Keywords Hyperspectral imaging $\cdot$ Flap perfusion $\cdot$ Flap monitoring $\cdot$ Non-invasive $\cdot$ Contactless

\section{Introduction}

Free flap and pedicled flap survival relies on adequate tissue perfusion. As free flaps are anastomosed to suitable donor vessels, pedicled flaps become translocated to the recipient

Electronic supplementary material The online version of this article (https://doi.org/10.1007/s00784-020-03382-6) contains supplementary material, which is available to authorized users.

D. G. E. Thiem

daniel.thiem@unimedizin-mainz.de

1 Department of Oral and Maxillofacial Surgery, Facial Plastic Surgery, University Medical Centre Mainz, Augustusplatz 2, 55131 Mainz, Germany

2 Department of Oral and Maxillofacial Surgery, School of Dentistry, Kyung Hee University, Seoul, Korea region while staying constantly connected to the supplying vessels. Flap failures may be attributed to arterial or venous occlusion due to thrombosis, external compression, vessel kinking, or the formation of haematoma [1]. In this context, evidence indicates that timely re-exploration significantly increases the rate of compromised flap salvage; thus, close postoperative monitoring is necessary in order to detect early signs of deterioration and to revise if necessary $[2,3]$. The risk of a total loss following free microvascular tissue transfer is approximately $2-6 \%$, mainly due to thrombotic events in the flow area of the microanastomosis $[4,5]$. A wealth of objective and subjective monitoring procedures have been reported in the past, but the current gold standard in monitoring flap perfusion is still based on a subjective clinical bedside assessment $[1,6]$. Here, Chubb et al. reviewed 1140 clinically monitored cases with overall 94 surgical revisions, showing a false-positive rate of $0.4 \%$ and an overall flap salvage rate of 
$62.8 \%$ [7]. Though an expert-investigator cannot be around at all time, another valid monitoring should be guaranteed after surgery. Hence, there is an increasing demand for an objective, reliable, and investigator-independent method to assess flap perfusion. Hyperspectral imaging (HSI) could be suitable for clinical use as it is a non-contact, non-ionising, and noninvasive monitoring technique that provides objective, reproducible, precise, and relevant information about physiological parameters in different medical fields of application like tissue perfusion measurements and wound assessment [8-10]. HSI processes the optical properties of a large area in a wavelength range from visual light (approx. 380-740 nm) to near infrared (750-1000 nm; NIR), acquiring a 3D data set ("hypercube") [10]. The TIVITA ${ }^{\mathrm{TM}}$ Tissue System software is trained to detect and measure haemoglobin with its derivatives oxyhaemoglobin $\left(\mathrm{O}_{2} \mathrm{Hb}\right)$, deoxyhaemoglobin $(\mathrm{HHb})$, and water to analyse the cutaneous and subcutaneous oxygenation pattern ( $\mathrm{StO}_{2}$ and NIR Perfusion Index) [10]. Therefore, this study aimed to investigate the primary question whether the use of hyperspectral imaging is feasible for objective and reproducible monitoring of flap perfusion in patients following reconstruction by free and pedicled flaps in comparison with clinical bedside assessment. Moreover, this study aimed to provide threshold values by means of an interpretation aid for clinicians to simplify the postoperative flap assessment.

\section{Material and methods}

\section{Patients}

In this prospective, non-randomised, clinical cohort study, patients with either free or pedicled flaps for reconstruction in the oro-maxillofacial area were included. The study was approved by the local ethic committee of Rhineland-Palate (registration number: 2019-14312) and was conducted in accordance with the protocol and in compliance with the moral, ethical, and scientific principles governing clinical research as set out in the Declaration of Helsinki of 1975 as revised in 1983. As the oral cavity is not accessible via HSI in the conscious patient at all sides due to light extinction, only free and pedicled flaps in the anterior lateral sides of the upper and lower jaws as well as flaps with an extraoral skin island were included. Exclusion criteria were cases without periodic measurements at several intervals following the flap inset.

\section{HSI imaging}

In this study, a new hyperspectral camera system (TIVITA ${ }^{\text {TM }}$ Tissue System, Diaspective Vision GmbH, Pepelow, Germany) was used. The HSI sensors generate a threedimensional (3D) data cube, where the spatial information is contained in the first two dimensions (resolution: $0.1 \mathrm{~mm} /$ pixel at $30-\mathrm{cm}$ distance), while the third dimension includes the spectral information (resolution, $5 \mathrm{~nm}$ ). The light measured includes the range from 500 (visible) to $1000 \mathrm{~nm}$ (near-infrared), whereby the light source is arranged directly around the camera lens and consists of six halogen spotlights providing $20 \mathrm{~W}$ each (Table 5). Briefly, HSI is based on the assessment of contiguous spectra (i.e. light of different wavelengths) individually re-emitted by molecules, whereby the molecule-specific re-emitted wave spectrum is generated on the basis of the light spectrum of the halogen spotlights initially emitted for examination. These physico-chemical raw data are then processed by computerised algorithms, specific for the respective molecule of interest (hyperspectral signatures), particularly haemoglobin, oxygenized haemoglobin, and water. After HSI, images are recorded over $10 \mathrm{~s}$, additional $8 \mathrm{~s}$ are needed to compute a RGD (red, green, and blue) truecolour image, and additional four pseudo-colour images, representing the physiologic parameters: tissue oxygenation/ superficial perfusion (approximately $0-1 \mathrm{~mm}$ depth) $\left(\mathrm{StO}_{2}\right.$ $(0-100 \%))$, near-infrared perfusion index/deep perfusion $(0$ $4 \mathrm{~mm}$ depth) (NIR as arbitrary units (0-100)), and distribution of haemoglobin (THI as arbitrary units (0-100)) and water (Tissue Water Index (TWI) as arbitrary units (0-100)) [11]. Haemoglobin plays a central role in HSI perfusion analysis and the differentiation between its oxygenated and deoxygenated form. This is due to the different absorption maxima of the two forms at different wavelengths. While oxygenated haemoglobin shows a double peak in the wavelength range between 500 and $600 \mathrm{~nm}$ and deoxygenated haemoglobin shows a single peak, both differ particularly at $760 \mathrm{~nm}$. Since the absorbance of haemoglobin in the range from 570 to $590 \mathrm{~nm}$ is high, electromagnetic radiation of a shorter wavelength shows a lower penetration depth in the tissue; thus, microcirculation is detected at a depth of up to $1 \mathrm{~mm}$. $\mathrm{StO}_{2}$ reflects the percentage of haemoglobin-oxygen-saturation in the capillary area of the tissue microcirculation, records arterial and venous blood, and displays changes in oxygen supply and consumption directly on site in the tissue. Thus, $\mathrm{StO}_{2}$ represents the tissue oxygen saturation, which is mainly based on the blood volume in the venous part $(75 \%)$ of the microcirculation and its oxygen saturation after delivery of oxygen to the tissue. Uniform standard or limit values for tissue oxygen saturation do not yet exist, although scientific studies to establish uniform limit values are still underway. The tissue oxygen saturation values of healthy volunteers are typically $50-70 \%$ [12]. The parameter NIR perfusion (near-infrared) describes the quality of blood flow, which is determined by the relative oxygen saturation of the haemoglobin and the relative haemoglobin content in the microcircular system in deeper tissue layers. The penetration depth can be 4 to $6 \mathrm{~mm}$. This parameter can be used to detect undersupplied areas of tissue in deeper layers. The colour scale ranges from red (high perfusion) to blue (low perfusion). THI (Tissue Haemoglobin 
Index) describes the existing haemoglobin distribution in the superficial microcircular system of the tissue area under consideration. This is an index value and not an absolute value. With this parameter, it is possible to detect arterial supply or venous outflow problems. The colour scale ranges from red (high haemoglobin content) to blue (low haemoglobin content). As an index value, TWI describes the relative water content in the considered tissue area. In general, the measured values alone are not meaningful, so a consideration of combinations (THI and NIR or THI and $\mathrm{StO}_{2}$ ) is necessary. The measured oxygen saturation is the percentage of oxygen bound to haemoglobin. This is important for the determination of tissue hypoxia, since the amount of dissolved oxygen in the tissue can be determined by measuring oxygen saturation. This is due to the fact that the oxygen binding curve relates oxygen saturation to a certain amount of dissolved oxygen. If one wants to know how much oxygen is absolutely available, one needs the blood flow in addition to the oxygen saturation. Only then can the absolute amount of inflow (which is determined by the blood flow and the arterial oxygen saturation) and absolute amount of outflow (which is determined by the blood flow and the capillary-venous oxygen saturation) be used to determine the amount of oxygen delivered to the tissue. Combinations of values with the possibility of drawing conclusions about tissue supply are as follows:

- High THI and low $\mathrm{StO}_{2}$ : venous congestion

- Low THI and low $\mathrm{StO}_{2}$ : arterial occlusion

- Low THI and high $\mathrm{StO}_{2}$ : following anastomosis

- Low $\mathrm{StO}_{2}$ and high NIR: deep tissue supply is given whereas superficial layers are undersupplied

- High $\mathrm{StO}_{2}$ and low NIR: critical situation as superficial supply can clinically hide saturation problems in deeper tissue layers

For accurate and reproducible measurements, the standard measuring distance was $50 \mathrm{~cm}$, represented by two separate indicator light points (red and green) in an overlapped position. Measurement time points were as follows, indicating the time after the inset of the flap: $\mathrm{t} 1=$ directly after inset (baseline), $\mathrm{t} 2=0-1 \mathrm{~h}, \mathrm{t} 3=4-8 \mathrm{~h}, \mathrm{t} 4=8-12 \mathrm{~h}, \mathrm{t} 5=12-24 \mathrm{~h}, \mathrm{t} 6=$ $24-48 \mathrm{~h}, \mathrm{t} 7=>48 \mathrm{~h}$. In the case of stalked grafts, the regularity of the measurements in the time interval $\mathrm{t} 3$ proved to be inconsistent, so that this time interval was not taken into account for the stalked grafts. The most likely explanation for this is the non-standardised monitoring of pedicled flaps, which led to missing measurements especially during the evening hours and at night. For quantification of $\mathrm{StO}_{2}$, NIR, THI, and TWI, the camera-specific software package (TIVITA ${ }^{\mathrm{TM}}$ Suite) was used in accordance to the literature [10]. In brief, at least three circularly shaped regions of interest (ROI), each with a diameter of $5 \mathrm{~mm}$, were manually positioned in the recorded area/field of interest. The circular region of interests are areas that contain the mean value of the spectral and spatial information contained therein per pixel. If the diameter of the ROIs were too big, the number of mean real areas on the graft surface to be examined would be automatically reduced, and the risk of charging for a less perfused area when including hyperperfused areas would increase. The diameter of $5 \mathrm{~mm}$ has proven to be suitable for placing at least three ROIs on the flap surface.

Hence, the number of ROIs was assessed according to the flap size. ROIs were placed at different positions, whereby its number was in dependency to the flaps' surface geometry (Fig. 1a-c) with ROIs along the border and at least one ROI in the flaps' centre whenever possible to achieve a homogeneous distribution of the measured area. For calculation, one ROI served as reference point and was located in the adjacent normal tissue. The clinical bedside examination took place before the hyperspectral analysis, so that the examiner was not influenced by the results of the HSI. Clinical evaluation criteria for flap perfusion were flap colour (pale = ischemia; livid $=$ venous congestion; or rosy $=$ normal perfusion $)$, recapillarisation time (fast $\leq 1.5$ (venous congestion); slow $\geq$ $3.0 \mathrm{~s}$ (reduced arterial blood flow); normal 1.5 to $3 \mathrm{~s}$ ), and subjective temperature (warm versus cold). In the case of transplants with impaired perfusion, the clinical assessment of the respective case was presented separately. For all other transplants, the clinical assessment was not presented.

\section{Statistics}

Raw data sets were saved in Excel® sheets (Microsoft Corporation, Redmond, USA) and subsequently transferred into SPSS Statistics ${ }^{\circledR}$ (version 23.0.0.2, MacOS X; SPSS Inc., IBM Corporation, Armonk, NY, USA). Data were expressed as median (MD), mean (m), standard deviation $(\mathrm{SD} \pm)$, minimum $(\min )$, maximum ( $\max )$, and standard error of the mean (SEM). Normal distribution was checked using a non-parametric Kolmogorov-Smirnov test (KS test), and results were analysed for statistical significance by the use of analysis of variance $\left(\mathrm{ANOVA}^{(\#)}\right)$, unpaired non-parametric Mann-Whitney $U$ tests $={ }^{(\$)}$, Wilcoxon-Whitney tests $={ }^{(\S)}$, and Students' $t$ test $={ }^{(*)}$. Considering the case number, all analyses are of explorative nature and $p$ values $\leq 0.05$ were termed significant for descriptive reasons only. For a proof of principle study, sample size calculation is not practicable; thus, this study is in accordance to other published proof of concept works dealing with similar group sizes [13, 14]. In the context of the sensitivity determination, the cases in which there was a decrease in perfusion parameters $\left(\mathrm{StO}_{2}\right.$ and NRI perfusion/increase in THI) prior to flap revision were classified as correctly positive. Since there were no false-negative cases in the cases shown, the test quality must be understood as descriptive. Line charts were used for illustration purposes. 

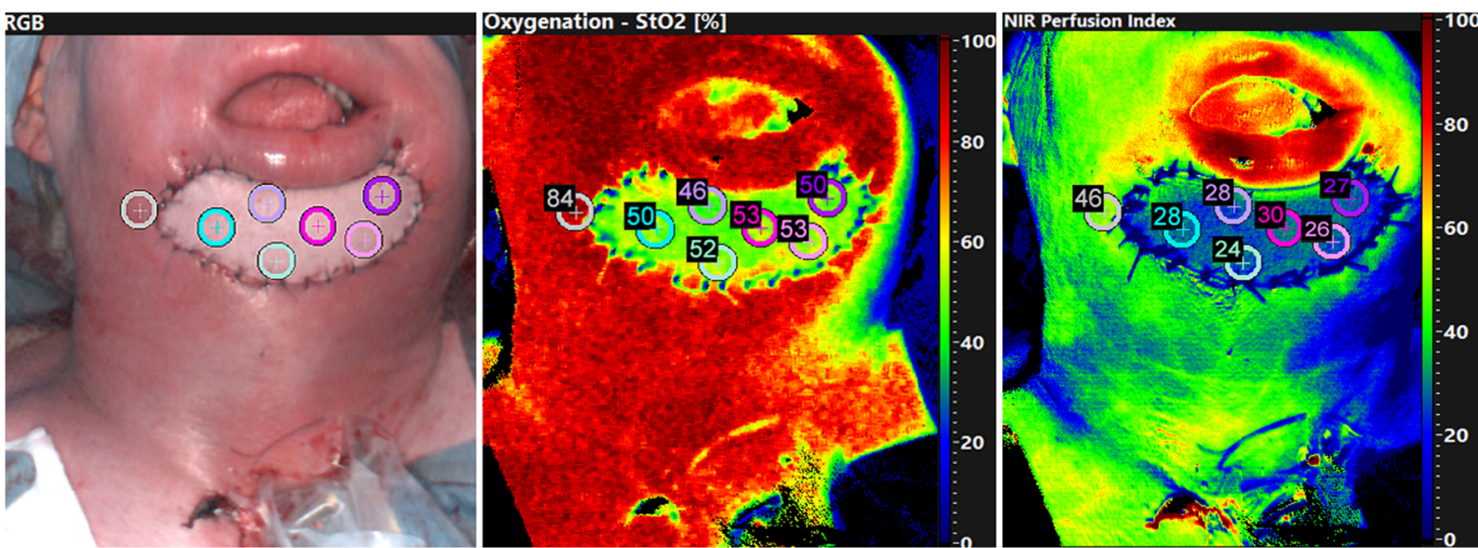

Fig. 1 Intraoperative hyperspectral imaging directly after flap inset (t1), showing primary reconstruction after tumour resection ( $t 4$ oral squamous cell carcinoma of the anterior mandibular gingiva with bone involvement) using ALT free flap (a-c). a RGB (red-green-blue) true colour image with seven coloured circles labelling the different regions of interest (ROIs).

\section{Results}

\section{Patients}

In this study, perfusion monitoring was performed on 25 free and 8 pedicled grafts in 33 patients intra- and postoperatively using HSI. In three cases with free flaps, a revision had to be carried out so that these were listed as an extra group with separate evaluation und were therefore not included in the main statistics. Free flaps included were radial forearm flap RF- $\mathrm{f}(n=12)$, osteocutaneous fibula flap OF- $\mathrm{f}(n=4)$, anterolateral tight flap as perforator flaps with two perforators ALT-f $(n=3)$, and osteocutaneous scapular flap OS-f $(n=3)$, and pedicled flaps were pectoralis major flap PM-f $(n=3)$, latissimus dorsi flap LD-f $(n=2)$, nasolabial flap NL-f ( $n=$ $1)$, and large-scale scalp rotation flap LSS-f $(n=2)$.

\section{Comparison between free and pedicled flaps}

\section{T1 (baseline)}

Directly after the inset of the flap, mean $\mathrm{StO}_{2}$ was significantly higher in FF $(70.3 \pm 13.6 \%)$ when compared with PF $(56.2 \pm$ $14.2 \%)\left(p=0.05^{(*)}\right)$. In contrast, mean values of NIR perfusion index $\left(p=0.82^{(*)}\right)$, THI $\left(p=0.97^{(\$)}\right)$, and TWI $(p=$ $\left.0.27^{(\$)}\right)$ appeared to be similar for free and pedicled flaps (Table 1).

\section{T2 (0-1 h)}

At $t 2$, mean parameter values of both, free and pedicled flaps, revealed similar in comparison between free and pedicled flaps with no significant differences $\left(\mathrm{StO}_{2}, p=0.75^{(*)}\right.$; NIR, $p=0.36^{(*)}$; THI, $p=0.19^{(\$)} ;$ TWI, $\left.p=1.0^{(\$)}\right)($ Table 1).
The grey circles serve as reference in the adjoining area. HSI analysis of $\mathrm{StO}_{2}$ (b) and NIR perfusion index (c) shows the different ROIs within the flap area and the adjacent reference-ROI (grey circle). The numbers indicate the ROIs' value in accordance to the colour scale bar on the right edge

\section{T3 (4-8 h)}

For the period $\mathrm{t} 3$ ( 4 to $8 \mathrm{~h}$ after flap inset), parameter means were as follows: $\mathrm{FF}_{-\mathrm{StO}_{2}}(m 37.9 \pm 17.0 \%)$; FF-NIR $(m 35.5$ $\pm 13.2)$; FF-THI $(m 41.5 \pm 29.3)$; FF-TWI $(m 44.0 \pm 15.7)$, whereby no data were available for PF.

\section{T4 (8-12 h)}

HSI measurements of t4 ( 8 to $12 \mathrm{~h}$ following flap inset) revealed no significant differences regarding perfusion parameters between free and pedicled flaps $\left(\mathrm{StO}_{2}, p=0.15^{(*)}\right.$; NIR, $p$ $=0.19^{(*)}$; THI, $p=0.57^{(\$)}$; TWI, $p=0.28^{(\$)}$ ) (Table 1).

\section{T5 (12-24 h)}

For HSI measurements between 12 and $24 \mathrm{~h}(\mathrm{t} 5)$, no significant differences of $\mathrm{StO}_{2}, p=0.76^{(*)}$; NIR, $p=0.56^{(*)}$; THI, $p$ $=0.47^{(\$)}$; and TWI, $p=0.65^{(\$)}$ revealed when comparing free and pedicled flaps (Table 1).

\section{T6 (24-48 h)}

For the period between 24 and $48 \mathrm{~h}$ following flap inset (t6), there were no significant differences between $\mathrm{StO}_{2}, p=$ $0.39^{(*)}$; NIR, $p=0.37^{(*)}$; THI, $p=0.11^{(\$)}$; and TWI, $p=$ $0.30^{(\$)}$, when comparing free and pedicled flaps (Table 1 ).

\section{$\mathrm{T7}(>48 \mathrm{~h})$}

Regarding HSI measurements $>48 \mathrm{~h}$ following flap inset ( $\mathrm{t} 7$ ), mean FF-THI (53.7 \pm 16.7$)$ was significantly increased compared with PF-THI $(29.0 \pm 11.3)\left(p=0.00^{(\$)}\right)$. However, $\mathrm{StO}_{2}$, NIR, and TWI were insignificantly different $\left(\mathrm{StO}_{2}, p=\right.$ 


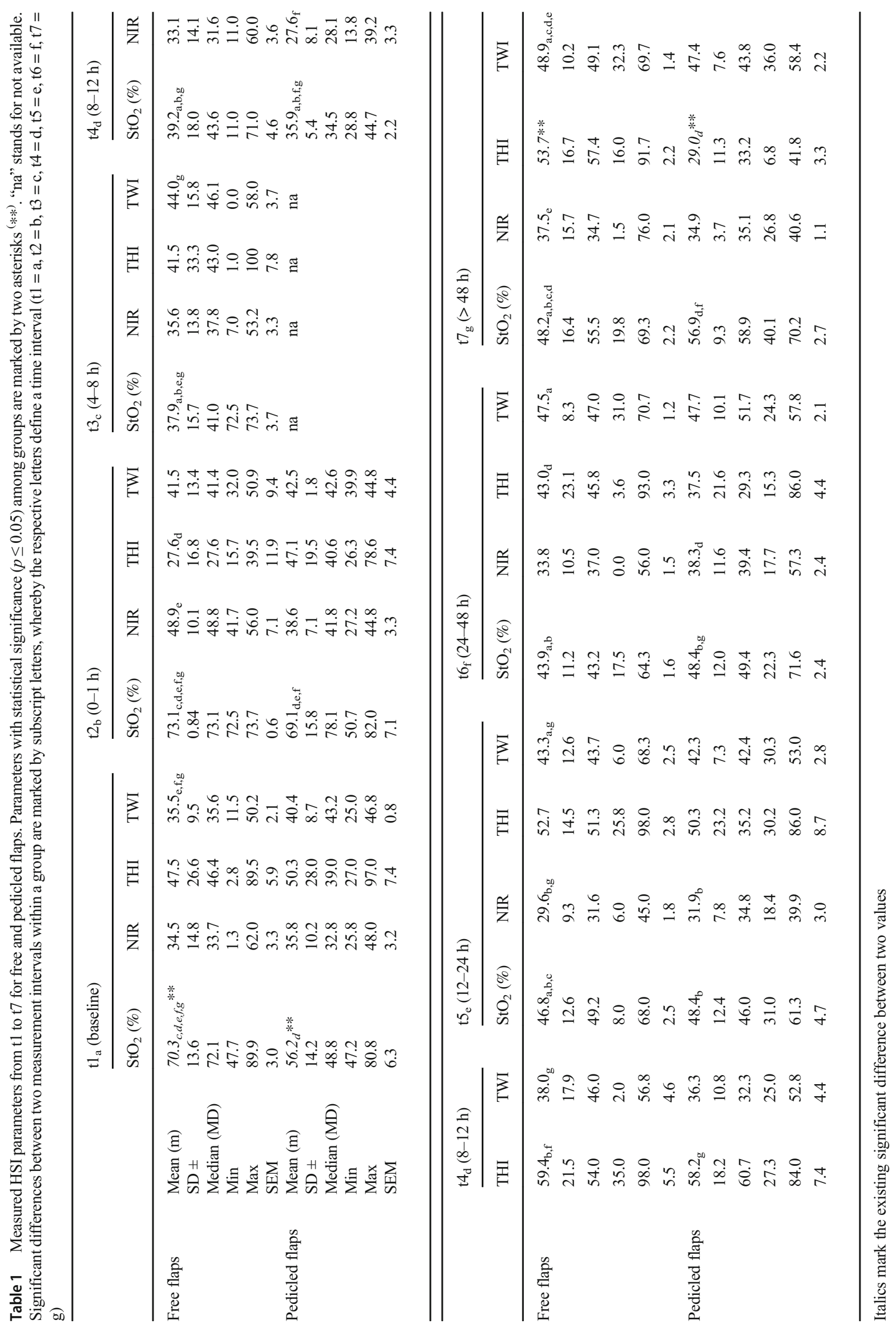


Table 2 Development of HSI parameters from baseline (t1) to postsurgical measurement time points following re-exploration

\begin{tabular}{|c|c|c|c|c|c|}
\hline & \multicolumn{2}{|c|}{ Presurgical } & & \multicolumn{2}{|l|}{ Postsurgical } \\
\hline & $\mathrm{t} 1$ & t6/hour 36 & & $\mathrm{t} 7 /$ hour 40 & $\mathrm{t} 7 /$ hour 67 \\
\hline $\mathrm{StO}_{2}(\%)$ & 59.4 & 42.4 & Re-entry & 36.3 & 20.2 \\
\hline NIR & 30.2 & 23.2 & & 30.8 & 22.7 \\
\hline THI & 4.4 & 45.9 & & 39.3 & 63.7 \\
\hline TWI & 28.7 & 40.2 & & 36.3 & 32.9 \\
\hline
\end{tabular}

$0.63^{(*)}$; NIR, $p=0.50^{(*)}$; TWI, $\left.p=0.62^{(\$)}\right)$ when comparing FF and PF (Table 1).

\section{Group-internal comparison of HSI parameters $\mathrm{StO}_{2}$, NRI perfusion, THI, and TWI) at different time points (t1-t7) for free flaps}

$\mathrm{StO}_{2}$

There was no significant difference between $\mathrm{t} 1$ and $\mathrm{t} 2$. In contrast, the tissue-oxygen-saturation $\left(\mathrm{StO}_{2}\right)$ was significantly different between $\mathrm{t} 1$ and $\mathrm{t} 3\left(p=0.00^{(*)}\right), \mathrm{t} 1$ and $\mathrm{t} 4(p=$ $\left.0.00^{(*)}\right)$, t1 and t5 $\left(p=0.00^{(*)}\right)$, t1 and t6 $\left(p=0.00^{(*)}\right)$, t1 and $\mathrm{t} 7\left(p=0.00^{(*)}\right), \mathrm{t} 2$ and $\mathrm{t} 3\left(p=0.01^{(*)}\right), \mathrm{t} 2$ and $\mathrm{t} 4(p=$ $\left.0.02^{(*)}\right)$, t2 and t5 $\left(p=0.001^{(*)}\right), \mathrm{t} 2$ and t6 $\left(p=0.004^{(*)}\right)$, t2 and $\mathrm{t} 7\left(p=0.015^{(*)}\right), \mathrm{t} 3$ and $\mathrm{t} 5\left(0.015^{(*)}\right)$, and $\mathrm{t} 3$ and $\mathrm{t} 7$ $\left(0.002^{(*)}\right)$ as well as between $\mathrm{t} 4$ and $\mathrm{t} 7\left(0.023^{(*)}\right)$. The other values are listed in Appendix 2a.

\section{NIR perfusion}

In the deeper tissue layers, the values were significantly different between the intervals t 2 and $\mathrm{t} 5\left(p=0.05^{(*)}\right)$ as well as between $\mathrm{t} 5$ and $\mathrm{t} 7\left(p=0.013^{(*)}\right)$. There was no difference between the other measurement times for NRI perfusion (Table 6).

Table 3 Development of HSI parameters from baseline (t1) to postsurgical measurement time points following re-exploration

\begin{tabular}{|c|c|c|c|c|c|c|}
\hline & \multicolumn{2}{|c|}{ Presurgical } & & \multicolumn{3}{|c|}{ Postsurgical } \\
\hline & $\mathrm{t} 1$ & $\begin{array}{l}\text { t6/hour } \\
40\end{array}$ & & $\begin{array}{l}\text { t } 7 \text { /hour } \\
46\end{array}$ & $\begin{array}{l}\text { t7/hour } \\
47\end{array}$ & $\begin{array}{l}\text { t7/hour } \\
67\end{array}$ \\
\hline $\begin{array}{l}\mathrm{StO}_{2} \\
\quad(\%)\end{array}$ & 67.4 & 28.7 & Re-entry & 55.7 & 58.2 & 57.0 \\
\hline NIR & 43.8 & 31.7 & & 17.7 & 37.0 & 50.0 \\
\hline THI & 48.0 & 33.3 & & 35.7 & 55.4 & 76.5 \\
\hline TWI & 32.4 & 47.7 & & 34.7 & 47.0 & 46.0 \\
\hline
\end{tabular}

THI

The Tissue Haemoglobin Index (THI) was significantly increased at $\mathrm{t} 4$ compared with $\mathrm{t} 2\left(p=0.049^{(\$)}\right)$ as well as between $\mathrm{t} 4$ and $\mathrm{t} 6\left(p=0.37^{(\$)}\right)$. At the other time points, there was no significant difference (Table 6).

TWI

For the TWI, significant differences were found between $\mathrm{t} 1$ and $\mathrm{t5}\left(p=0.021^{(\$)}\right), \mathrm{t} 1$ and $\mathrm{t} 6\left(p=0.00^{(\$)}\right), \mathrm{t} 1$ and $\mathrm{t} 7(p=$ $\left.0.00^{(\$)}\right), \mathrm{t} 3$ and $\mathrm{t} 7\left(p=0.036^{(\$)}\right)$, and $\mathrm{t} 4$ and $\mathrm{t} 7\left(p=0.035^{(\$)}\right)$, and between $\mathrm{t} 5$ and $\mathrm{t} 7\left(p=0.036^{(\$)}\right)$. At the other time points, there was no significant difference (Table 6).

\section{Group-internal comparison of $\mathrm{HSI}$ parameters $\mathrm{CSO}_{2}$, NRI perfusion, THI, and TWI) at different time points (t1-t7) for pedicled flaps}

$\mathrm{StO}_{2}$

Tissue-oxygen-saturation $\left(\mathrm{StO}_{2}\right)$ in pedicled flaps was significantly different between $\mathrm{t} 1$ and $\mathrm{t} 4\left(p=0.006^{(*)}\right), \mathrm{t} 2$ and $\mathrm{t} 4(p$ $\left.=0.000^{(*)}\right), \mathrm{t} 2$ and $\mathrm{t} 5\left(p=0.004^{(*)}\right), \mathrm{t} 2$ and $\mathrm{t} 6\left(p=0.001^{(*)}\right), \mathrm{t} 4$ and t6 $\left(p=0.022^{(*)}\right)$, and $\mathrm{t} 4$ and $\mathrm{t} 7\left(p=0.001^{(*)}\right)$ as well as between $\mathrm{t} 6$ and $\mathrm{t} 7\left(p=0.044^{(*)}\right)$. The other values are listed in Appendix 2b.

\section{NIR perfusion}

NIR perfusion showed significant differences over time between $t 4$ and t6 $\left(p=0.015^{(*)}\right)$. The other values are listed in Appendix 2b.

\section{THI}

The Tissue Haemoglobin Index (THI) was significantly increased at $\mathrm{t} 4$ compared with $\mathrm{t} 7\left(p=0.007^{(\$)}\right)$. The other values are listed in Appendix 2b.

\section{TWI}

No significant differences were revealed for the tissue water index (Table 6).

\section{Cases with surgical re-entry}

In overall $3 / 22$ patients with FF reconstruction, surgical reexploration was performed in consequence of flap deterioration whereby the salvage rate was $33 \%(1 / 3)$. HSI measurements conducted prior to $=$ after flap inset ${ }^{(\text {pre-revision) }}$ and after revision ${ }^{\text {(post-revision) }}$ presented as follows: 
Table 4 Development of HSI parameters from baseline (t1) to postsurgical measurement time points following re-exploration

\begin{tabular}{|c|c|c|c|c|c|c|c|}
\hline & \multicolumn{2}{|c|}{ Presurgical } & & \multicolumn{2}{|c|}{ Postsurgical } & & \multirow{2}{*}{$\begin{array}{l}\text { Presurgical } \\
\text { t7/hour } 61\end{array}$} \\
\hline & $\mathrm{t} 1$ & $\begin{array}{l}\text { t3/ } \\
\text { hour } 5\end{array}$ & & $\begin{array}{l}\text { t4/ } \\
\text { hour } 9\end{array}$ & $\begin{array}{l}\text { t } 5 \text { /hour } \\
14\end{array}$ & & \\
\hline $\begin{array}{r}\mathrm{StO}_{2} \\
\quad(\%)\end{array}$ & 62.9 & 32.0 & Re-entry & 36.5 & 46.4 & Re-entry & 33.0 \\
\hline NIR & 29.0 & 21.5 & & 16.8 & 40.0 & & 31.2 \\
\hline THI & 38.5 & 95.3 & & 95.5 & 97.0 & & 77.1 \\
\hline TWI & 29.3 & 19.0 & & 15.0 & 26.6 & & 30.4 \\
\hline
\end{tabular}

\section{Case $1^{\text {(OF-f) }}$ : Re-exploration was performed $36 \mathrm{~h}$ after flap inset} HSI measurements ${ }^{\text {(pre-revision) }}$ showed a decline of $\mathrm{StO}_{2}(-$ $17 \%)$ and NIR (-7) as well as an increase of the THI (+ 41.5) and TWI (+ 11.5) from baseline (t1) to hour 36 (t6). HSI measurements ${ }^{\text {(post-revision) }}$ were consistent with the further clinical course of an impaired perfusion due to venous congestion (bluish colour, immediate capillary refill, and deep red bleeding on puncture) leading to flap loss and explantation $\left(\mathrm{StO}_{2}-6.1 \%^{(\mathrm{t} 6 / \text { hour }} 40\right)$ to $20.9 \%^{\text {(t7/hour } 58)}$, NIR $+7.6^{(\mathrm{t} 6 / \text { hour }}$ ${ }^{40)}$ to $-0.5^{(\text {t7/hour } 67)}$ THI $-6.6^{(\text {t6/hour } 40)}$ to $+17.8^{(\text {t7/hour } 67)}$, TWI $-3.2^{(\text {t6/hour } 40)}$ to $\left.-7.3^{(\text {t7 } / \text { hour } 67)}\right)$. Detailed information is shown in Table 2.

\section{Case $2^{(\mathrm{RF}-\mathrm{f})}$ : Re-exploration was performed $40 \mathrm{~h}$ after flap inset} HSI measurements ${ }^{\text {(pre-revision) }}$ revealed a decline of $\mathrm{StO}_{2}(-$ $38.7 \%)$, NIR (-26.1), and THI (-16.3) as well as an increase of the TWI (+15.3) from baseline (t1) to hour $40(\mathrm{t} 6)$. These findings were in accordance with the clinical assessment likely to an impaired perfusion caused by an arterial occlusion (sudden pale colour, prolonged capillary refill time ( $>5 \mathrm{~s}$ ), absence of bleeding on needle puncture). After re-exploration, perfusion parameters increased continuously over time (Table 3).

Case $3^{\text {(RF-f) }}$ : Take back and re-exploration were done 5 and $61 \mathrm{~h}$ following flap inset HSI measurements ${ }^{\text {(pre-revision) }}$ revealed a decrease of $\mathrm{StO}_{2}(-30.9 \%)$, NIR $(-7.5)$, and TWI $(-10.3)$ as well as an increase of the THI $(+56)$ from baseline (t1) to hour 5 (t3). Hence, HSI measurements were in accordance with the clinical bedside assessment showing signs of a perfusion disorder (bluish colour, immediate capillary refill, and deep red bleeding on puncture), characteristic for a venous congestion. After the first take back with following revision at hour 5 , flap perfusion initially increased until hour 14. However, flap perfusion again decreased within the further course leading to another take back, re-exploration of the cervical anastomosis, and final flap explantation in consequence of arterial and venous occlusion (no reflow phenomenon) at hour 61 (Table 4).

\section{Discussion}

Based on the present results, this study demonstrated the successful application of HSI for perioperative monitoring following free and pedicled flap transplantation. In addition, the findings provide an interpretation aid for clinicians to simplify postoperative flap assessment. Regarding HSI measurements immediately after flap inset ( $\mathrm{t} 1)$, direct perfusion parameter $\left(\mathrm{StO}_{2}\right)$ revealed significantly $\left(\mathrm{StO}_{2}, p=0.05^{(*)}\right)$ lower in pedicled flaps $\left(\mathrm{PF}_{-} \mathrm{StO}_{2}, 56.2 \pm 14.2 \%\right)$ when compared with free flaps (FF-StO $2,70.3 \pm 14.8 \%$ ). This could be caused by an increased blood flow as a result of iatrogenic denervation during vascular deposition with subsequent decrease in vascular resistance $[15,16]$. Over time, flap perfusion decreased in both, free and pedicled flaps, with lowest values as follows: FF$\mathrm{StO}_{2}{ }^{\left({ }^{(13)}\right.} 37.8 \%$, FF-NIR ${ }^{(\mathrm{t} 5)}$ 29.7/100; ${\mathrm{PF}-\mathrm{StO}_{2}}^{\left({ }^{(4)}\right)} 35.8 \%$; and $\mathrm{PF}-N I R^{(\mathrm{t} 4)} 27.6 / 100$. In the further course, the perfusion increased in both flap types; however, neither $\mathrm{StO}_{2}$ nor NIR reached intraoperative levels (t1), which is in line with the findings of a former animal study presented by this study group [9].

With a correct true-positive detection rate of $3 / 3$ impaired free flaps, the sensitivity of HSI imaging in this study was $100 \%$. However, including two events of venous thrombus (cases 1 and 3) and one arterial occlusion (case 2), the salvage rate was only $33 \%(1 / 3)$, whereby perfusion disorders became clinically apparent 36 (case 1), 40 (case 2), and $5 \mathrm{~h}$ (case 3) following flap inset, representing - analogue to the literaturethe critical time frame of 24 to $72 \mathrm{~h}$ for complications [2, 17, 18]. On closer examination of the hyperspectral parameters, signs of a disturbed perfusion could already be seen hours before the actual take back and revision of anastomosis. Case 1: By showing a decrease of superficial tissue oxygenation $\left(\mathrm{StO}_{2}, 59.4\right.$ to $\left.42.5 \%(-17 \%)\right)$ and deep perfusion (NIR, 30.2 to $23.2(-7)$ in combination with an increase of THI (4.4 to $45.9(+41.5)$ and TWI $(28.7$ to $40.2(+11.5)$, HSI analysis reliably confirmed the clinical findings, characteristic for a venous congestion [9] and representing the basis for revision at hour 36. After surgical re-exploration and revision of the venous anastomosis, flap perfusion however remained poor with $\left.\mathrm{StO}_{2}\left(21.5 \% \%^{(\mathrm{t} 7 / \text { hour }} 58\right)\right)$, NIR $\left(22.7^{(\mathrm{t} 7 / \text { hour } 67)}\right)$, THI $\left(63.7^{(\mathrm{t} 7 / \text { hour }}\right.$ $\left.{ }^{67)}\right)$, and TWI $\left(32.9^{(t 7 / \text { hour } 67)}\right)$, leading to a complete flap failure with subsequent flap explantation. Already at the time of measurement after 15 and $20 \mathrm{~h}$, a constant decrease in superficial $\left(\mathrm{StO}_{2}\right)$ and deep perfusion (NIR) was observed. This was additionally accompanied by an increase in the surrogate parameters THI and TWI. Thus, the hyperspectral analysis showed clear signs of incipient venous congestion $36 \mathrm{~h}$ prior to clinical diagnosis. As edema formation in soft tissue could be either based on renal dysfunction or impaired venous drainage, the TWI (Tissue Water Index) is a surrogate parameter providing information about the tissue water content [9], typically increased early (see case 1) from venous congestion and extravascular fluid leakage or after ischemia-induced endothelial 
death with a time lag. Regarding case 2, clinical signs of flap deterioration (sudden pale colour, prolonged capillary refill time, absence of bleeding on needle puncture) became clinically obvious $40 \mathrm{~h}$ after flap inset, coming along with a change of HSI parameters $\left(\mathrm{StO}_{2}, 67.4\right.$ to 28.7 ( $\left.-38.7 \%\right)$; NIR, 43.8 to 17.7 (-26.1); THI, 48.0 to 31.7 (-16.3); and TWI, 32.4 to 47.7 $(+15.3)$ ). After re-exploration and revision of the arterial anastomosis within $1 \mathrm{~h}$, flap perfusion improved clinically (pink colour, capillary refill after 2 to $3 \mathrm{~s}$ ) which was also confirmed by HSI measurements during the further course $\left(61.5 \% \%^{(t 7 / h o u r}\right.$ $\left.{ }^{59)}\right)$, NIR $\left(58.5^{(\text {t7/hour } 59)}\right)$; THI $\left(67.5^{(\text {t7/hour } 59)}\right)$, and TWI $\left.\left(55.5^{(t 7 / h o u r} 59\right)\right)$. According to the HSI analysis, however, the perfusion parameters already showed a decrease from hour 25 to $27\left(\mathrm{StO}_{2},-19 \%\right.$ and $\left.\mathrm{NIR},-20\right)$ and thus gave an indication on a compensated course $13 \mathrm{~h}$ prior to clinical diagnosis. Together with the parallel value progression of THI, this appears to be consistent with the hyperspectral signature pattern characteristic for arterial perfusion disorders. In case 3, flap perfusion declined clinically $5 \mathrm{~h}$ after flap inset, showing signs characteristic for venous congestion (bluish colour, immediate capillary refill, and deep red bleeding on puncture). This again was reflected in a typical value curve of the hyperspectral parameters $\left(\mathrm{StO}_{2} 76.5\right.$ to $32.0 \%$ (- $\left.44.5 \%\right)$ ), NIR (44.8 to 21.5 (23.3), THI (91.0 to $95.3(+4.3))$. After partial externalisation of the FF for tension relief and initial increase of direct perfusion parameters $\left(\mathrm{StO}_{2}\right.$ and $\left.\mathrm{NIR}\right)$, flap perfusion deteriorated again clinically $61 \mathrm{~h}$ after flap inset, which was also reflected in the HSI measurements $\left(\mathrm{StO}_{2}\right.$ down to $\left.33.0 \%^{(\mathrm{t} 7 / \text { hour }} 61\right)$; NIR, down to $31.2^{\text {(t7/hour } 61)}$; THI, down to $77.1^{\text {(t7/hour } 61)}$; TWI, $30.4^{(\text {t7 } 7 \text { hour }}$ ${ }^{61)}$ ) leading to surgical re-exploration and subsequent flap explantation due to a persisting arterial occlusion. Clinical evaluation was always in line with HSI and performed by an experienced surgeon (PWK). Taking THI into account, however, a critical increase is already evident after $1.5 \mathrm{~h}$, giving an early ( $3.5 \mathrm{~h}$ prior to clinical diagnosis) indication of venous congestion. In addition, prior to the second revision, a decrease of superficial $\left(\mathrm{StO}_{2}\right)$ and deep perfusion (NIR) was already evident $25 \mathrm{~h}$ after flap inset, thus $36 \mathrm{~h}$ prior to the clinical diagnosis. However, this conclusion can only be drawn with regard to the further course, since parameters were within an acceptable range. In accordance to the course of case 1 , usually venous congestion causes a gradual decline in flow values that often lasts for hours, while arterial occlusion leads to an abrupt decline [19]. In comparison with pulse oximetry as another noninvasive technique to assess tissue oxygenation, the HSI provides discriminable monitoring of both, arterial and venous oxygenation [20]. Yoshino et al. was unable to distinguish between arterial and venous problems when monitoring 37 intraoral free flaps with a laser Doppler flowmeter [21]. In contrast, Hölzle et al. described the successful application of $\mathrm{O}_{2} \mathrm{C}$ (oxygen-to-see, LEA-Medizintechnik $\mathrm{GmbH}$, Gießen, Germany), a device combination of a laser Doppler flowmeter and a tissue spectrometer, for free flap monitoring and early recognition of flap failure [22]. For measurements, a probe has to be continuously in contact with the flap surface, giving quantitative information about a limited area only. Flap monitoring with laser-induced fluorescence of indocyanine green (ICG) was described as extremely sensitive and able to detect even partial flap necrosis [23]. However, monitoring requires expertise and the injection of fluorescein carries the risk for anaphylactic reactions; thus, ICG is contraindicated in patients with iodine allergy $[1,24]$. Besides many other methods for flap monitoring, e.g. confocal microscopy, $\mathrm{pH}$ measurement, Sidestream Dark Field Imaging, temperature measurement, and the usage of implantable Doppler probes, the HSI works completely contactless conveying much more spectral information than truecolour RGB (red, green, blue) or other multispectral data systems. In addition, due to image acquisition, HSI by TIVITA $^{\text {TM }}$ provides both spectral and spatial information about the respective area of interest (visible flap surface). However, it should be noted that ambient light conditions always slightly differ between the measurements having potential impact on the parameters' values. One further disadvantage of this HSI system is the housing size of the measuring unit allowing only limited illumination of the posterior sections of the oral cavity (Table 5). The examination quality of free muscle flaps with split skin coverage is also questionable. Current investigations of the authors showed a high dependency on the quality of the split-skin covering, since subcutaneous seroma accumulations due to an insufficient split-skin-fit leads to a falsification of values. Former studies have already described the successful usage of the HSI whereas Köhler et al. described HSI as a valuable method for evaluating ischaemic conditioning effects of the gastric conduit during oesophagectomy [25]. To the authors' knowledge, this is the first study assessing the feasibility of HSI to monitor flap perfusion following reconstructive operations in the field of oral and maxillofacial surgery. The data shown here demonstrate for the first time the successful clinical use of hyperspectral technology for transplant monitoring and underline the preclinical results of this research group. Conclusive statements on the exact definition of threshold values cannot be made on the basis of the available results, but they provide an important contribution to further investigations. Based on the number of cases, particularly those needing subsequent re-exploration, the present results have to be classified as of descriptive nature. Hence, further clinical studies must be conducted in order to generate more data that supports the development of threshold values for therapy recommendations. In this context, great potential may arises from a combination of deep learning technologies and HSI [26]. Another research approach of the working group is the fusion of artificial intelligence (e.g. neuronal network approaches) and hyperspectral technology. In the foreseeable future, this would eliminate the need for result interpretation by the user and thus enable safe clinical application by the less experienced physician or even nursing staff in order to save resources. 


\section{Conclusion}

Hyperspectral imaging permits early and objective detection of flap failure prior to clinical assessment. Based on the present results, the necessity for anastomosis revision arose in cases of $\mathrm{StO}_{2}$ values $<45 \%$ and NIR values below 25/100. A gradual decline of $\mathrm{StO}_{2}$ and NIR in combination with an increase of THI indicated venous congestion. In contrast, a sudden decline of $\mathrm{StO}_{2}$, NIR, and THI was shown. A multicentre approach is needed to establish threshold values, given the generally low number of revisions.

Author contributions All authors of this manuscript had substantial contribution to conception and design or acquisition, analysis, and interpretation of data; all revised it critically for important intellectual content and did final approval of the version to be published. All authors read and approved the final manuscript. D.G.E. Thiem (daniel.thiem@unimainz.de) takes responsibility for the integrity of the work as a whole, from inception to finished article.

Funding information Open Access funding provided by Projekt DEAL.

\section{Compliance with ethical standards}

Conflict of interest The authors declare that they have no conflict of interest.

Ethical approval All procedures performed in studies involving human participants were in accordance with the ethical standards of the institutional and/or national research committee and with the 1964 Helsinki declaration and its later amendments or comparable ethical standards.

Informed consent Informed consent was obtained from all individual participants included in the study.

\section{Appendix}

Table 5 (A) shows the construction of the measuring unit with (1) the measuring head with lens, halogen lamps, and own control unit attached to a telescopic arm. This is attached to a mobile trolley with control computer, operating elements (keyboard and mouse), and screen (2). (B) shows the user interface of the software with selection of the body region to be measured (here the face). (C) shows a live measurement of a person (here a medical colleague). (D) shows the alignment of the measuring unit with focus light switched on with projection on the right cheek

\begin{tabular}{llll}
\hline $\begin{array}{l}\text { Dependant } \\
\text { variable }\end{array}$ & $\begin{array}{l}\text { Measurement time } \\
\text { point (interval) }\end{array}$ & $\begin{array}{l}\text { Measurement } \\
\text { interval }\end{array}$ & $\begin{array}{l}\text { Significance } \\
(p=)\end{array}$ \\
\hline $\mathrm{StO}_{2}(\%)$ & $\mathrm{t} 1$ & $\mathrm{t} 2$ & $.810^{(*)}$ \\
& & $\mathrm{t} 3$ & $.000^{(*)}$ \\
& $\mathrm{t} 4$ & $.000^{(*)}$ \\
& $\mathrm{t} 5$ & $.000^{(*)}$ \\
& $\mathrm{t} 6$ & $.000^{(*)}$ \\
& $\mathrm{t} 7$ & $.000^{(*)}$
\end{tabular}

Table 5 (continued)

\begin{tabular}{|c|c|c|c|}
\hline $\begin{array}{l}\text { Dependant } \\
\text { variable }\end{array}$ & $\begin{array}{l}\text { Measurement time } \\
\text { point (interval) }\end{array}$ & $\begin{array}{l}\text { Measurement } \\
\text { interval }\end{array}$ & $\begin{array}{l}\text { Significance } \\
(p=)\end{array}$ \\
\hline & \multirow[t]{6}{*}{$\mathrm{t} 2$} & $\mathrm{t} 1$ & $.810^{(*)}$ \\
\hline & & $\mathrm{t} 3$ & $.001^{(*)}$ \\
\hline & & t4 & $.002^{(*)}$ \\
\hline & & t5 & $.012^{(*)}$ \\
\hline & & t6 & $.004^{(*)}$ \\
\hline & & t7 & $.015^{(*)}$ \\
\hline & \multirow[t]{6}{*}{$\mathrm{t} 3$} & $\mathrm{t} 1$ & $.000^{(*)}$ \\
\hline & & $\mathrm{t} 2$ & $.001^{(*)}$ \\
\hline & & $\mathrm{t} 4$ & $.560^{(*)}$ \\
\hline & & t5 & $.015^{(*)}$ \\
\hline & & t6 & $.063^{(*)}$ \\
\hline & & $\mathrm{t} 7$ & $.002^{(*)}$ \\
\hline & \multirow[t]{6}{*}{ t4 } & $\mathrm{t} 1$ & $.000^{(*)}$ \\
\hline & & $\mathrm{t} 2$ & $.002^{(*)}$ \\
\hline & & $\mathrm{t} 3$ & $.560^{(*)}$ \\
\hline & & t5 & $.085^{(*)}$ \\
\hline & & t6 & $.280^{(*)}$ \\
\hline & & t7 & $.023^{(*)}$ \\
\hline & \multirow[t]{6}{*}{$\mathrm{t} 5$} & $\mathrm{t} 1$ & $.000^{(*)}$ \\
\hline & & $\mathrm{t} 2$ & $.012^{(*)}$ \\
\hline & & $\mathrm{t} 3$ & $.015^{(*)}$ \\
\hline & & $\mathrm{t} 4$ & $.085^{(*)}$ \\
\hline & & t6 & $.317^{(*)}$ \\
\hline & & t7 & $.647^{(*)}$ \\
\hline & \multirow[t]{6}{*}{ t6 } & $\mathrm{t} 1$ & $.000^{(*)}$ \\
\hline & & $\mathrm{t} 2$ & $.004^{(*)}$ \\
\hline & & $\mathrm{t} 3$ & $.063^{(*)}$ \\
\hline & & t4 & $.280^{(*)}$ \\
\hline & & t5 & $.317^{(*)}$ \\
\hline & & $\mathrm{t} 7$ & $.077^{(*)}$ \\
\hline & \multirow[t]{6}{*}{$\mathrm{t} 7$} & $\mathrm{t} 1$ & $.000^{(*)}$ \\
\hline & & $\mathrm{t} 2$ & $.015^{(*)}$ \\
\hline & & $\mathrm{t} 3$ & $.002^{(*)}$ \\
\hline & & t4 & $.023^{(*)}$ \\
\hline & & $\mathrm{t} 5$ & $.647^{(*)}$ \\
\hline & & t6 & $.077^{(*)}$ \\
\hline \multirow{12}{*}{$\begin{array}{l}\text { NIR } \\
\quad \text { perfusion }\end{array}$} & \multirow[t]{6}{*}{$\mathrm{t} 1$} & $\mathrm{t} 2$ & $.152^{(*)}$ \\
\hline & & $\mathrm{t} 3$ & $.780^{(*)}$ \\
\hline & & $\mathrm{t} 4$ & $.496^{(*)}$ \\
\hline & & t5 & $.188^{(*)}$ \\
\hline & & t6 & $.724^{(*)}$ \\
\hline & & $\mathrm{t} 7$ & $.440^{(*)}$ \\
\hline & \multirow[t]{6}{*}{$\mathrm{t} 2$} & $\mathrm{t} 1$ & $.152^{(*)}$ \\
\hline & & $\mathrm{t} 3$ & $.123^{(*)}$ \\
\hline & & $\mathrm{t} 4$ & $.087^{(*)}$ \\
\hline & & $\mathrm{t} 5$ & $.050^{(*)}$ \\
\hline & & t6 & $.111^{(*)}$ \\
\hline & & t7 & $.231^{(*)}$ \\
\hline
\end{tabular}


Table 5 (continued)

\begin{tabular}{llll}
\hline $\begin{array}{l}\text { Dependant } \\
\text { variable }\end{array}$ & $\begin{array}{l}\text { Measurement time } \\
\text { point (interval) }\end{array}$ & $\begin{array}{l}\text { Measurement } \\
\text { interval }\end{array}$ & $\begin{array}{l}\text { Significance } \\
(p=)\end{array}$ \\
\hline
\end{tabular}

t3

$\mathrm{t} 4$

t5

t6

THI

t1

t2

t7

t3

3

$.780^{(*)}$

$.123^{(*)}$

$.691^{(*)}$

$.336^{(*)}$

$.995^{(*)}$

$.289^{(*)}$

$.496^{(*)}$

$.087^{(*)}$

$.691^{(*)}$

$.622^{(*)}$

$.636^{(*)}$

$.136^{(*)}$

$.188^{(*)}$

$.050^{(*)}$

$.336^{(*)}$

$.622^{(*)}$

$.216^{(*)}$

$.013^{(*)}$

$.724^{(*)}$

$.111^{(*)}$

$.995^{(*)}$

$.636^{(*)}$

$.216^{(*)}$

$.133^{(*)}$

$.440^{(*)}$

$.231^{(*)}$

$.289^{(*)}$

$.136^{(*)}$

$.013^{(*)}$

$.133^{(*)}$

$.192^{(\$)}$

$.715^{(\$)}$

$.108^{(\$)}$

$.434^{(\$)}$

$.545^{(\$)}$

$.485^{(\$)}$

$.192^{(\$)}$

$.255^{(\$)}$

$.046^{(\$)}$

$.104^{(\$)}$

$.261^{(\$)}$

$.113^{(\$)}$

$.715^{(\$)}$

$.255^{(\$)}$

$.059^{(\$)}$

$.257^{(\$)}$

$.887^{(\$)}$

$.276^{(\$)}$
Table 5 (continued)

\begin{tabular}{ll}
$\begin{array}{l}\text { Dependant } \\
\text { variable }\end{array}$ & $\begin{array}{l}\text { Measurement time } \\
\text { point (interval) }\end{array}$ \\
\hline
\end{tabular}

Measurement

interval

Significance

variable

t4

t1

t1

t2

t3

t5

t6

t7

t5

t1

t2

t3

$(p=)$

$108^{(\$)}$

$.046^{(\$)}$

$.059^{(\$)}$

$.325^{(\$)}$

$.016^{(\$)}$

$.210^{(\$)}$

$.434^{(\$)}$

$.104^{(\$)}$

$.257^{(\$)}$

$.325^{(\$)}$

$.103^{(\$)}$

$.839^{(\$)}$

t6

$.545^{(\$)}$

$.261^{(\$)}$

$.887^{(\$)}$

$.016^{(\$)}$

$.103^{(\$)}$

$.082^{(\$)}$

t7

$.485^{(\$)}$

$.113^{(\$)}$

$.276^{(\$)}$

$.210^{(\$)}$

$.839^{(\$)}$

$.082^{(\$)}$

$.467^{(\$)}$

$.213^{(\$)}$

$.687^{(\$)}$

$.049^{(\$)}$

$.000^{(\$)}$

$.000^{(\$)}$

$.467^{(\$)}$

$.854^{(\$)}$

$.590^{(\$)}$

$.965^{(\$)}$

$.604^{(\$)}$

$.386^{(\$)}$

$.213^{(\$)}$

$.854^{(\$)}$

$.437^{(\$)}$

$.576^{(\$)}$

$.062^{(\$)}$

$.005^{(\$)}$

$.687^{(\$)}$

$.590^{(\$)}$

$.437^{(\$)}$

$.165^{(\$)}$

$.007^{(\$)}$

$.000^{(\$)}$ 
Table 5 (continued)

\begin{tabular}{llll}
\hline $\begin{array}{l}\text { Dependant } \\
\text { variable }\end{array}$ & $\begin{array}{l}\text { Measurement time } \\
\text { point (interval) }\end{array}$ & $\begin{array}{l}\text { Measurement } \\
\text { interval }\end{array}$ & $\begin{array}{l}\text { Significance } \\
(p=)\end{array}$ \\
\hline \multirow{2}{*}{ t5 } & $\mathrm{t} 1$ & $.049^{(\$)}$ \\
$\mathrm{t} 2$ & $.965^{(\$)}$ \\
$\mathrm{t} 3$ & $.576^{(\$)}$ \\
$\mathrm{t} 4$ & $.165^{(\$)}$ \\
$\mathrm{t} 6$ & $.144^{(\$)}$ \\
$\mathrm{t} 7$ & $.011^{(\$)}$ \\
$\mathrm{t} 1$ & $.000^{(\$)}$ \\
$\mathrm{t} 2$ & $.604^{(\$)}$ \\
$\mathrm{t} 3$ & $.062^{(\$)}$ \\
& $\mathrm{t} 6$ & $.007^{(\$)}$ \\
& $\mathrm{t} 4$ & $.144^{(\$)}$ \\
& $\mathrm{t} 5$ & $.193^{(\$)}$ \\
& $\mathrm{t} 7$ & $.000^{(\$)}$ \\
& $\mathrm{t} 1$ & $.386^{(\$)}$ \\
& $\mathrm{t} 2$ & $.005^{(\$)}$ \\
& $\mathrm{t} 3$ & $.000^{(\$)}$ \\
& $\mathrm{t} 7$ & $.011^{(\$)}$ \\
& $\mathrm{t} 5$ & $.193^{(\$)}$ \\
& $\mathrm{t} 6$ &
\end{tabular}

Italics mark the existing significant difference between two values

Table 6 Tabular listing of the significance tests within the groups free (a) and pedicled (b) flaps between the different measurement intervals. Here ${ }^{(*)}$ stands for the statistical significance test with the Students $t$ test, and (\$) for the test with Mann-Whitney $U$ test

\begin{tabular}{llll}
\hline $\begin{array}{l}\text { Dependant } \\
\text { variable }\end{array}$ & $\begin{array}{l}\text { Measurement timepoint } \\
\text { (interval) }\end{array}$ & $\begin{array}{l}\text { Measurement } \\
\text { interval }\end{array}$ & $\begin{array}{l}\text { Significance } \\
(p=)\end{array}$ \\
\hline $\mathrm{StO}_{2}(\%)$ & $\mathrm{t} 1$ & $\mathrm{t} 2$ & $.085^{(*)}$ \\
& & $\mathrm{t} 4$ & $.006^{(*)}$ \\
$\mathrm{t} 5$ & $.260^{(*)}$ \\
& $\mathrm{t} 6$ & $.182^{(*)}$ \\
$\mathrm{t} 7$ & $.902^{(*)}$ \\
& & $\mathrm{t} 1$ & $.085^{(*)}$ \\
& $\mathrm{t} 2$ & $\mathrm{t} 4$ & $.000^{(*)}$ \\
& & $\mathrm{t} 5$ & $.004^{(*)}$ \\
& $\mathrm{t} 6$ & $.001^{(*)}$ \\
& $\mathrm{t} 7$ & $.055^{(*)}$ \\
& $\mathrm{t} 4$ & $\mathrm{t} 1$ & $.006^{(*)}$ \\
& $\mathrm{t} 2$ & $.000^{(*)}$ \\
& $\mathrm{t} 5$ & $.058^{(*)}$ \\
& $\mathrm{t} 6$ & $.022^{(*)}$ \\
& $\mathrm{t} 5$ & $\mathrm{t} 7$ & $.001^{(*)}$ \\
& $\mathrm{t} 1 \mathrm{t}$ & $.260^{(*)}$ \\
& & $\mathrm{t} 2$ & $.004^{(*)}$ \\
& & $.058^{(*)}$
\end{tabular}

Table 6 (continued)

\begin{tabular}{|c|c|c|c|}
\hline $\begin{array}{l}\text { Dependant } \\
\text { variable }\end{array}$ & $\begin{array}{l}\text { Measurement timepoint } \\
\text { (interval) }\end{array}$ & $\begin{array}{l}\text { Measurement } \\
\text { interval }\end{array}$ & $\begin{array}{l}\text { Significance } \\
(p=)\end{array}$ \\
\hline & & t6 & $.998^{(*)}$ \\
\hline & & $\mathrm{t} 7$ & $.130^{(*)}$ \\
\hline & t6 & $\mathrm{t} 1$ & $.182^{(*)}$ \\
\hline & & $\mathrm{t} 2$ & $.001^{(*)}$ \\
\hline & & $\mathrm{t} 4$ & $.022^{(*)}$ \\
\hline & & t5 & $.998^{(*)}$ \\
\hline & & t7 & $.044^{(*)}$ \\
\hline & t7 & $\mathrm{t} 1$ & $.902^{(*)}$ \\
\hline & & $\mathrm{t} 2$ & $.055^{(*)}$ \\
\hline & & $\mathrm{t} 4$ & $.001^{(*)}$ \\
\hline & & $\mathrm{t} 5$ & $.130^{(*)}$ \\
\hline & & t6 & $.044^{(*)}$ \\
\hline \multirow[t]{30}{*}{ NIR_mean } & $\mathrm{t} 1$ & t2 & $.633^{(*)}$ \\
\hline & & $\mathrm{t} 4$ & $.150^{(*)}$ \\
\hline & & t5 & $.472^{(*)}$ \\
\hline & & t6 & $.590^{(*)}$ \\
\hline & & t7 & $.861^{(*)}$ \\
\hline & t2 & $\mathrm{t} 1$ & $.633^{(*)}$ \\
\hline & & $\mathrm{t} 4$ & $.055^{(*)}$ \\
\hline & & $\mathrm{t} 5$ & $.219^{(*)}$ \\
\hline & & t6 & $.940^{(*)}$ \\
\hline & & $\mathrm{t} 7$ & $.459^{(*)}$ \\
\hline & t4 & $\mathrm{t} 1$ & $.150^{(*)}$ \\
\hline & & $\mathrm{t} 2$ & $.055^{(*)}$ \\
\hline & & t5 & $.412^{(*)}$ \\
\hline & & t6 & $.015^{(*)}$ \\
\hline & & t7 & $.120^{(*)}$ \\
\hline & $\mathrm{t} 5$ & $\mathrm{t} 1$ & $.472^{(*)}$ \\
\hline & & $\mathrm{t} 2$ & $.219^{(*)}$ \\
\hline & & $\mathrm{t} 4$ & $.412^{(*)}$ \\
\hline & & t6 & $.114^{(*)}$ \\
\hline & & t7 & $.490^{(*)}$ \\
\hline & t6 & $\mathrm{t} 1$ & $.590^{(*)}$ \\
\hline & & $\mathrm{t} 2$ & $.940^{(*)}$ \\
\hline & & $\mathrm{t} 4$ & $.015^{(*)}$ \\
\hline & & t5 & $.114^{(*)}$ \\
\hline & & t7 & $.313^{(*)}$ \\
\hline & $\mathrm{t} 7$ & $\mathrm{t} 1$ & $.861^{(*)}$ \\
\hline & & t2 & $.459^{(*)}$ \\
\hline & & $\mathrm{t} 4$ & $.120^{(*)}$ \\
\hline & & t5 & $.490^{(*)}$ \\
\hline & & t6 & $.313^{(*)}$ \\
\hline \multirow[t]{6}{*}{ THI mean } & t1 & t2 & $.803^{(\$)}$ \\
\hline & & $\mathrm{t} 4$ & $.525^{(\$)}$ \\
\hline & & t5 & $.999^{(\$)}$ \\
\hline & & t6 & $.205^{(\$)}$ \\
\hline & & t7 & $.053^{(\$)}$ \\
\hline & t2 & $\mathrm{t} 1$ & $.803^{(\$)}$ \\
\hline
\end{tabular}


Table 6 (continued)

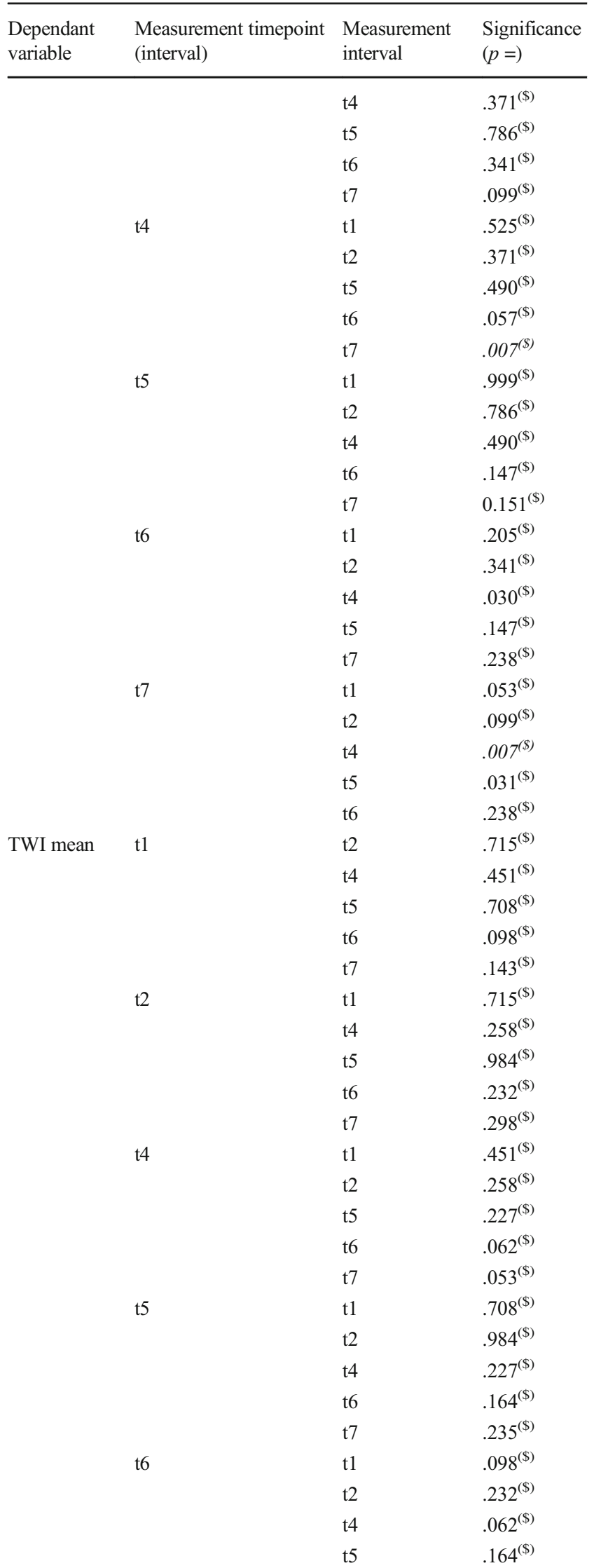

Table 6 (continued)

\begin{tabular}{llll}
\hline $\begin{array}{l}\text { Dependant } \\
\text { variable }\end{array}$ & $\begin{array}{l}\text { Measurement timepoint } \\
\text { (interval) }\end{array}$ & $\begin{array}{l}\text { Measurement } \\
\text { interval }\end{array}$ & $\begin{array}{l}\text { Significance } \\
(p=)\end{array}$ \\
\hline & $\mathrm{t} 7$ & $.921^{(\$)}$ \\
& $\mathrm{t} 1$ & $.143^{(\$)}$ \\
& $\mathrm{t} 2$ & $.298^{(\$)}$ \\
$\mathrm{t} 4$ & $.053^{(\$)}$ \\
& $\mathrm{t} 5$ & $.235^{(\$)}$ \\
& $\mathrm{t} 6$ & $.921^{(\$)}$ \\
\hline
\end{tabular}

Italics mark the existing significant difference between two values

Open Access This article is licensed under a Creative Commons Attribution 4.0 International License, which permits use, sharing, adaptation, distribution and reproduction in any medium or format, as long as you give appropriate credit to the original author(s) and the source, provide a link to the Creative Commons licence, and indicate if changes were made. The images or other third party material in this article are included in the article's Creative Commons licence, unless indicated otherwise in a credit line to the material. If material is not included in the article's Creative Commons licence and your intended use is not permitted by statutory regulation or exceeds the permitted use, you will need to obtain permission directly from the copyright holder. To view a copy of this licence, visit http://creativecommons.org/licenses/by/4.0/.

\section{References}

1. Chae MP, Rozen WM, Whitaker IS, Chubb D, Grinsell D, Ashton MW, Hunter-Smith DJ, Lineaweaver WC (2015) Current evidence for postoperative monitoring of microvascular free flaps: a systematic review. Ann Plast Surg 74(5):621-632. https://doi.org/10.1097/ SAP.0b013e3181f8cb32

2. Yang Q, Ren ZH, Chickooree D, Wu HJ, Tan HY, Wang K, He ZJ, Gong CJ, Ram V, Zhang S (2014) The effect of early detection of anterolateral thigh free flap crisis on the salvage success rate, based on 10 years of experience and 1072 flaps. Int J Oral Maxillofac Surg 43(9):1059-1063. https://doi.org/10.1016/j.ijom.2014.06.003

3. Chang EI, Carlsen BT, Festekjian JH, Da Lio AL, Crisera CA (2013) Salvage rates of compromised free flap breast reconstruction after recurrent thrombosis. Ann Plast Surg 71(1):68-71. https://doi. org/10.1097/SAP.0b013e31824680c8

4. Dolan RT, Butler JS, Murphy SM, Cronin KJ (2012) Health-related quality of life, surgical and aesthetic outcomes following microvascular free flap reconstructions: an 8-year institutional review. Ann R Coll Surg Engl 94(1):43-51. https://doi.org/10.1308/ 003588412X13171221498749

5. Kansy K, Mueller AA, Mucke T, Kopp JB, Koersgen F, Wolff KD, Zeilhofer HF, Hölzle F, Pradel W, Schneider M, Kolk A, Smeets R, Acero J, Hoffmann J, Reconstruction DCGfM (2014) Microsurgical reconstruction of the head and neck-current concepts of maxillofacial surgery in Europe. J Craniomaxillofac Surg 42 (8): 1610-1613. doi:https://doi.org/10.1016/j.jcms.2014.04.030

6. Jallali N, Ridha H, Butler PE (2005) Postoperative monitoring of free flaps in UK plastic surgery units. Microsurgery 25(6):469-472. https://doi.org/10.1002/micr.20148

7. Chubb D, Rozen WM, Whitaker IS, Acosta R, Grinsell D, Ashton MW (2010) The efficacy of clinical assessment in the postoperative 
monitoring of free flaps: a review of 1140 consecutive cases. Plast Reconstr Surg 125(4):1157-1166. https://doi.org/10.1097/PRS. 0b013e3181d0ac95

8. Calin MA, Coman T, Parasca SV, Bercaru N, Savastru R, Manea D (2015) Hyperspectral imaging-based wound analysis using mixture-tuned matched filtering classification method. J Biomed Opt 20(4). https://doi.org/10.1117/1.Jbo.20.4.046004

9. Grambow E, Dau M, Holmer A, Lipp V, Frerich B, Klar E, Vollmar B, Kämmerer PW (2018) Hyperspectral imaging for monitoring of perfusion failure upon microvascular anastomosis in the rat hind limb. Microvasc Res 116:64-70. https://doi.org/10.1016/j.mvr. 2017.10.005

10. Holmer A, Marotz J, Wahl P, Dau M, Kämmerer PW (2018) Hyperspectral imaging in perfusion and wound diagnosticsmethods and algorithms for the determination of tissue parameters. Biomed Tech (Berl) 63(5):547-556. https://doi.org/10.1515/bmt2017-0155

11. Bashkatov AN, Genina EA, Kochubey VI, Tuchin VV (2005) Optical properties of human skin, subcutaneous and mucous tissues in the wavelength range from 400 to $2000 \mathrm{~nm}$. J Phys D Appl Phys 38(15):2543-2555. https://doi.org/10.1088/0022-3727/38/15/004

12. Bickler PE, Feiner JR, Rollins MD (2013) Factors affecting the performance of 5 cerebral oximeters during hypoxia in healthy volunteers. Anesth Analg 117(4):813-823. https://doi.org/10. 1213/ANE.0b013e318297d763

13. McAdams DR, Stapels CJ, Kolodziejski NJ, Chung YG, Vishwanath K, Helton MC, Pakela JM, Lee SY (2017) Compact dual-mode diffuse optical system for blood perfusion monitoring in a porcine model of microvascular tissue flaps. J Biomed Opt 22(12). https://doi.org/10.1117/1.Jbo.22.12.121609

14. Khan M, Pretty CG, Amies AC, Balmer J, Banna HE, Shaw GM, Geoffrey Chase J (2017) Proof of concept non-invasive estimation of peripheral venous oxygen saturation. Biomed Eng Online 16(1): 60. https://doi.org/10.1186/s12938-017-0351-x

15. McKee NH, Clarke HM, Nigra CA, Manktelow RT (1982) A study of blood flow and pressure in the vessels supplying a free flap. Plast Reconstr Surg 69(1):68-73

16. Saltzman D, DeLano FA, Schmid-Schonbein GW (1992) The microvasculature in skeletal muscle. VI. Adrenergic innervation of arterioles in normotensive and spontaneously hypertensive rats. Microvasc Res 44(3):263-273

17. Salama AR, McClure SA, Ord RA, Pazoki AE (2009) Free-flap failures and complications in an American oral and maxillofacial surgery unit. Int J Oral Maxillofac Surg 38(10):1048-1051. https:// doi.org/10.1016/j.ijom.2009.05.002
18. Sweeny L, Topf M, Wax MK, Rosenthal EL, Greene BJ, Heffelfinger R, Krein H, Luginbuhl A, Petrisor D, Troob SH, Hughley B, Hong S, Zhan T, Curry J (2019) Shift in the timing of microvascular free tissue transfer failures in head and neck reconstruction. Laryngoscope. https://doi.org/10.1002/lary.28177

19. Yuen JC, Feng Z (2000) Monitoring free flaps using the laser Doppler flowmeter: five-year experience. Plast Reconstr Surg 105(1):55-61. https://doi.org/10.1097/00006534-20000100000009

20. Gioux S, Mazhar A, Lee BT, Lin SJ, Tobias AM, Cuccia DJ, Stockdale A, Oketokoun R, Ashitate Y, Kelly E, Weinmann M, Durr NJ, Moffitt LA, Durkin AJ, Tromberg BJ, Frangioni JV (2011) First-in-human pilot study of a spatial frequency domain oxygenation imaging system. J Biomed Opt 16(8):086015. https://doi.org/10.1117/1.3614566

21. Yoshino K, Nara S, Endo M, Kamata N (1996) Intraoral free flap monitoring with a laser Doppler flowmeter. Microsurgery 17(6): 337-340. https://doi.org/10.1002/(SICI)1098-2752(1996)17: 6<337::AID-MICR9>3.0.CO;2-E

22. Hölzle F, Loeffelbein DJ, Nolte D, Wolff KD (2006) Free flap monitoring using simultaneous non-invasive laser Doppler flowmetry and tissue spectrophotometry. J Craniomaxillofac Surg 34(1):25-33. https://doi.org/10.1016/j.jcms.2005.07.010

23. Issing WJ, Naumann C (1996) Evaluation of pedicled skin flap viability by $\mathrm{pH}$, temperature and fluorescein: an experimental study. J Craniomaxillofac Surg 24(5):305-309

24. Su Z, Ye P, Teng Y, Zhang L, Shu X (2012) Adverse reaction in patients with drug allergy history after simultaneous intravenous fundus fluorescein angiography and indocyanine green angiography. J Ocul Pharmacol Ther 28(4):410-413. https://doi.org/10. 1089/jop.2011.0221

25. Kohler H, Jansen-Winkeln B, Maktabi M, Barberio M, Takoh J, Holfert N, Moulla Y, Niebisch S, Diana M, Neumuth T, Rabe SM, Chalopin C, Melzer A, Gockel I (2019) Evaluation of hyperspectral imaging (HSI) for the measurement of ischemic conditioning effects of the gastric conduit during esophagectomy. Surg Endosc. https://doi.org/10.1007/s00464-019-06675-4

26. Signoroni A, Savardi M, Baronio A, Benini S (2019) Deep learning meets hyperspectral image analysis: a multidisciplinary review. J Imaging 5(5). https://doi.org/10.3390/jimaging5050052

Publisher's note Springer Nature remains neutral with regard to jurisdictional claims in published maps and institutional affiliations. 